\title{
(2) OPEN ACCESS \\ Tobacco industry tactics in response to cigarette excise tax increases in Mauritius
}

\author{
Julie Berthet Valdois (10, ${ }^{1}$ Corne Van Walbeek, ${ }^{1}$ Hana Ross, ${ }^{1}$ Hema Soondram, ${ }^{2}$ \\ Bhavish Jugurnath, ${ }^{2}$ Marie Chan Sun, ${ }^{3}$ Deowan Mohee ${ }^{4,5}$
}

${ }^{1}$ School of Economics, University of Cape Town, Rondebosch, South Africa

${ }^{2}$ Faculty of Law and Management, Department of Finance and Accounting, University of Mauritius, Reduit, Mauritius

${ }^{3}$ Faculty of Science, University of Mauritius, Reduit, Mauritius

${ }^{4}$ NGO VISA, Curepipe, Mauritius ${ }^{5}$ African Tobacco Control Alliance, Lome, Togo

\section{Correspondence to}

Julie Berthet Valdois, School of Economics, University of Cape Town, Rondebosch 7701, South Africa;

jberthet.valdois@gmail.com

Received 5 June 2019 Revised 14 August 2019 Accepted 4 September 2019 Published Online First 4 November 2019

Check for updates

\section{(c) Author(s) (or their} employer(s)) 2020. Re-use permitted under CC BY-NC. No commercial re-use. See rights and permissions. Published by BMJ.

To cite: Berthet Valdois J, Van Walbeek C, Ross H, et al. Tob Control

2020;29:e115-e118.

\section{ABSTRACT}

Background In response to high smoking rates, especially among men, Mauritius launched a National Action Plan on Tobacco Control in 2008. It changed its tax system from a mixed system to a uniform specific system. Despite these interventions, cigarette consumption and smoking prevalence in Mauritius decreased only marginally in the subsequent decade. Method Using publicly available data, we decompose the retail price of cigarettes into tax and net-of-tax components, between 2011 and 2017. We cover premium, popular and economy cigarettes.

Results Since its introduction in 2008, the nominal excise tax was increased six times. Between 2011 and 2017 , the real value of the excise tax increased by $47 \%$. Meanwhile, British American Tobacco (BAT) increased the real net-of-tax price of premium cigarettes by $61.8 \%$ and of popular cigarettes by $47.2 \%$, thus overshifting the tax increase. On economy cigarettes, BAT decreased the real net-of-tax price by $14.7 \%$, thus undershifting the excise tax increase.

Conclusion Through its pricing strategy, BAT has greatly undermined Mauritius's tobacco control policy. However, BAT cannot continue undershifting the excise tax on economy brands, since the net-of-tax proportion of the retail price is very low already. BAT would have little choice but to increase the retail price on economy brands in response to future excise tax increases. The government of Mauritius is encouraged to keep the specific excise tax structure but to increase the rate at which it is levied.

\section{INTRODUCTION}

Mauritius is an island in the Indian Ocean, with a population of about 1.3 million people. In 2008, $40.3 \%$ of adult men and $3.7 \%$ of adult women in Mauritius smoked cigarettes. ${ }^{1}$ This was the highest smoking prevalence rate for men in Africa. ${ }^{2}$ In response to the high smoking prevalence and Mauritius's obligations under the WHO's Framework Convention on Tobacco Control (WHO FCTC), which it ratified in 2004, the country adopted a 4-year National Action Plan on Tobacco Control in 2008. ${ }^{3}$

Other than introducing a variety of legislative measures and a well-publicised antismoking campaign, the government of Mauritius adopted a uniform specific tax on cigarettes in July 2008 . $^{1}$ At the time, the rate was set at Rs 2200 per 1000 cigarettes (Rs 44 (US\$1.62) per pack). In the subsequent 10 years, the rate was increased six times. The uniform specific tax structure replaced a mixed system (ie, both ad valorem and specific tax components) that had been in place since 2001 . Before 2001, the excise tax was levied as a pure ad valorem tax.

Despite these tax and non-tax interventions, smoking prevalence in Mauritius has remained broadly unchanged since 2008. Between 2008 and 2016 smoking prevalence among men decreased marginally from $40.3 \%$ to $38.5 \%$, while smoking prevalence among women increased from $3.7 \%$ to $4.1 \%$. $^{45}$

This short report focuses on trends in cigarette taxation in Mauritius, and the tobacco industry's pricing strategy in response to the tax changes since 2011. We will show that the tobacco industry used two completely different pricing strategies for the various price categories to protect its revenues and undermine the government's tobacco control strategy.

\section{Data and methods}

The data were collected from a variety of secondary sources. The study covers the period 2011-2017. The excise tax rate, which has been levied as a specific tax since July 2008, was obtained from the respective annual budget speech for each of the years under study. ${ }^{6}$ The total number of cigarettes sold was obtained from the customs office. Price data were retrieved from media releases, newspaper archives, British American Tobacco (BAT)'s administrative documents and the tobacco-control focal point's reports to the WHO FCTC. ${ }^{7}$ The Consumers' Price Index (CPI) were retrieved from World Bank. ${ }^{8}$

The retail price of cigarettes consists of two main components: (1) taxes (comprising both excise tax and value-added tax (VAT)) and (2) the net-of-tax price. The net-of-tax price is calculated as the retail price less the VAT amount (calculated as $1 /(1+$ (VAT rate $/ 100)) \times R P$, where $\mathrm{RP}$ is the retail price) and the specific excise tax per pack. To calculate the real prices, the nominal prices were adjusted by the CPI (base 2017).

\section{RESULTS}

\section{Trends in the excise tax}

The uniform specific excise tax, introduced in July 2008, was levied at a rate of Rs 2200 per thousand cigarettes (Rs 44 or US\$1.62 per pack). Since 2008, the excise tax was adjusted six times (table 1). These increases were typically larger than the inflation rate. By July 2017 the real (inflation-adjusted) value of the excise tax was $75.6 \%$ higher than its July 2008 level. There has been no adjustment in the excise tax since July 2017. 


\begin{tabular}{|c|c|c|c|c|c|}
\hline \multirow[b]{2}{*}{ Period } & \multirow[b]{2}{*}{$\begin{array}{l}\text { Specific excise duty } \\
\text { (Rs per } 1000 \text { sticks) } \\
\text { (nominal) }\end{array}$} & \multirow[b]{2}{*}{$\begin{array}{l}\text { Excise duty Rs/ } \\
\text { pack ( } 20 \text { cigarettes) } \\
\text { (nominal) }\end{array}$} & \multicolumn{3}{|c|}{ Converted to calendar year } \\
\hline & & & Year & $\begin{array}{l}\text { Excise duty Rs/ } \\
\text { pack ( } 20 \text { cigarettes) } \\
\text { (nominal) }\end{array}$ & $\begin{array}{l}\text { Excise duty } \\
\text { Rs/pack ( } 20 \\
\text { cigarettes) (real } \\
\text { price base 2017) }\end{array}$ \\
\hline \multirow[t]{3}{*}{1 July 2008-19 November 2010} & 2200 & 44.0 & 2008 & 44.0 & 58.2 \\
\hline & & & 2009 & 44.0 & 56.8 \\
\hline & & & 2010 & 44.9 & 56.3 \\
\hline 20 November 2010 -4 November 2011 & 2750 & 55.0 & 2011 & 56.4 & 66.3 \\
\hline 5 November 2011-9 November 2012 & 3160 & 63.2 & 2012 & 64.5 & 73.1 \\
\hline 10 November 2012-12 November 2013 & 3540 & 70.8 & 2013 & 71.4 & 78.1 \\
\hline 13 November 2013-30 June 2016 & 3717 & 74.3 & 2014 & 74.3 & 78.8 \\
\hline 1 July 2016-June 2017 & 4646 & 92.9 & 2015 & 74.3 & 77.8 \\
\hline \multirow[t]{2}{*}{1 July 2017-present } & 5111 & 102.2 & 2016 & 83.6 & 86.7 \\
\hline & & & 2017 & 97.6 & 97.6 \\
\hline
\end{tabular}

Note: (1) Calendar year 2008 refers to prices after the uniform tax was implemented (from July to December 2008); (2) The excise tax data for the calendar years are weighted average tax values, based on the number of months that the excise tax was effective during that year.

Sources: Mauritius Revenue Authority, Annual Budget speeches and Ministry of Finance \& Economic Development.

\section{Trends in cigarette prices, by price category}

About 15 different cigarette brands are sold in Mauritius. These brands fall into three well-defined price categories: (1) premium brands (eg, Benson \& Hedges, Camel, Dunhill); (2) popular brands (Matinee and Embassy) and (3) economy brands (eg, Matelot, Pall Mall). According to the International Tobacco Control (ITC) project data, premium brands had about $8 \%$ market share in 2010, while popular and economy brands had market shares of $85 \%$ and $7 \%$, respectively. ${ }^{9}$

In 2011, the price of premium cigarettes was about 14\% higher than popular brands, whereas the price of economy cigarettes was about $10 \%$ lower (table 2). By 2017 , the price of premium cigarettes was 20\% higher than the popular cigarettes, while the price of economy cigarettes was $21 \%$ lower, illustrating a clear divergence in the retail prices over this period.

Between 2011 and 2017, the real price of premium cigarettes increased by $54 \%$, compared with a $47 \%$ increase in the real price of popular brand cigarettes over the same period. In contrast, the real price of economy brand cigarettes increased by only $29 \%$ over this period.

In figure 1 , the real retail price of cigarettes, in the three price categories, is decomposed into its two tax components (excise tax and VAT) and the net-of-tax price. For the period 2011 to
2017, the net-of-tax price has increased for popular brands and especially the premium brands but has decreased substantially for the economy brands.

The excise tax changes and the tobacco industry's pricing strategy between 2011 and 2017 are summarised in table 3 . During this period, the industry increased the real net-of-tax price of premium cigarettes by Rs 33 per pack (62\%) in response to a Rs $31(47 \%)$ increase in the real excise tax. A pricing strategy of increasing the net-of-tax price in response to an increase in the excise tax is called overshifting. The tobacco industry greatly overshifted the excise tax increase on premium cigarettes, resulting in a substantially greater increase in the real retail price (54\%) than would have been the case had they kept the real net-of-tax price constant (26\%, not shown in table 3$)$. A broadly similar pattern applies for popular brand cigarettes, although the degree of overshifting is not as pronounced. As a result of the overshifting of the excise tax, the retail price of popular brand cigarettes increased by Rs 57 per pack (47\%), as opposed to $30 \%$ had the industry not increased the net-of-tax price.

For economy brand cigarettes, the tobacco industry substantially undershifted the excise tax increase, as illustrated by the Rs $4(15 \%)$ decrease in the net-of-tax price. Undershifting occurs when the tobacco industry decreases the net-of-tax price

Table 2 Nominal and real price of cigarettes, by price category since 2011

\begin{tabular}{|c|c|c|c|c|c|c|c|c|}
\hline \multirow[b]{3}{*}{ Year } & \multicolumn{3}{|c|}{$\begin{array}{l}\text { Nominal retail price (Rs per pack; } \\
\text { weighted average for the year) }\end{array}$} & \multicolumn{3}{|c|}{$\begin{array}{l}\text { Real retail price (Rs per pack; weighted } \\
\text { average for the year) }\end{array}$} & \multicolumn{2}{|c|}{$\begin{array}{l}\text { Premium/discount percentage relative to popular } \\
\text { brand }\end{array}$} \\
\hline & Premium & Popular & Economy & Premium & Popular & Economy & Premium & Economy \\
\hline & (1) & (2) & (3) & (4) & (5) & (6) & (7) & (8) \\
\hline 2011 & 118 & 103 & 93 & 138 & 121 & 109 & 14 & -10 \\
\hline 2012 & 132 & 119 & 107 & 149 & 135 & 121 & 10 & -10 \\
\hline 2013 & 143 & 141 & 117 & 156 & 154 & 128 & 1 & -17 \\
\hline 2014 & 155 & 145 & 125 & 164 & 154 & 133 & 7 & -14 \\
\hline 2015 & 165 & 145 & 130 & 173 & 152 & 136 & 14 & -11 \\
\hline 2016 & 183 & 158 & 133 & 189 & 163 & 137 & 16 & -16 \\
\hline 2017 & 213 & 178 & 140 & 213 & 178 & 140 & 20 & -21 \\
\hline \multicolumn{9}{|c|}{ Percentage change } \\
\hline 2011-2017 & $81 \%$ & $73 \%$ & $51 \%$ & $54 \%$ & $47 \%$ & $29 \%$ & & \\
\hline
\end{tabular}

Note: (1) Where nominal retail prices were increased during a particular year, we calculated a weighted average retail price (in Rs per pack) for the calendar year, and (2) the real retail price (in Rs per pack) is calculated at the displayed nominal price, divided by the average CPI value of the appropriate year. 


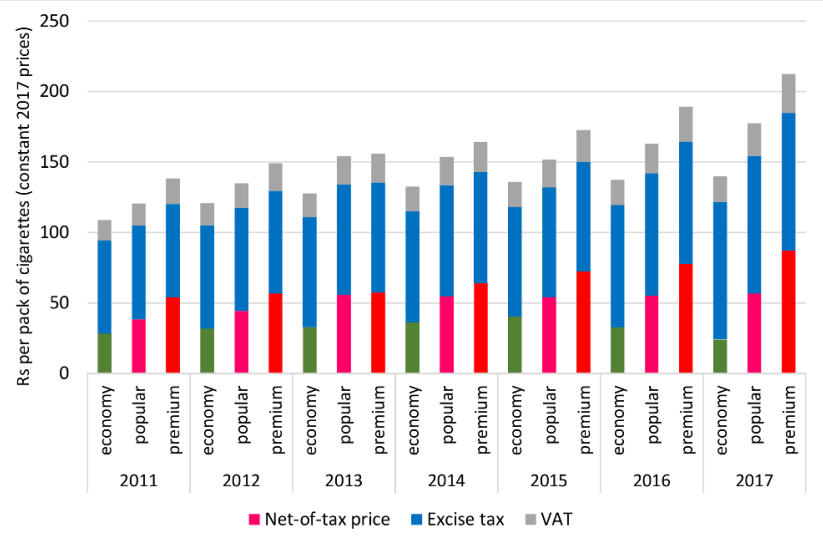

Figure 1 Decomposition of the real retail price (base 2017) of cigarettes in Mauritius, 2011-2017.

in response to an increase in the excise tax, thus reducing (but not necessarily eliminating) the tax impact on the retail price. Between 2011 and 2017, the real price of economy cigarettes increased by Rs 31 per pack (29\%), but it would have increased by $33 \%$ had the tobacco industry not borne a part of the tax increase.

As a result of the industry's pricing strategy, the price range between the discount and premium brands have increased from Rs 29 in 2011 to Rs 73 in 2017 (all in constant 2017 prices). The proportion of excise tax in the retail price has also changed substantially. In 2011 the excise tax burden (expressed as a percentage of the retail price) on premium brands was $48 \%$, while for economy brands, it was 61\%. In 2017, despite the substantial increase in the real excise tax, the excise tax burden on premium brands had decreased to $46 \%$, while for economy brands, it had increased to $70 \%$. For popular brands, between 2011 and 2017, the excise tax burden remained unchanged at $55 \%$.

\section{DISCUSSION}

Our analysis indicates that the industry's pricing strategy has substantially undermined the effectiveness of the excise tax increases that the Mauritian government implemented in the past decade. As in many countries, the market for cigarettes in Mauritius is a near monopoly, with BAT having a 91\% market share. ${ }^{10}$ It has used this monopoly power to its advantage.

The cigarette market in Mauritius can be divided into three price segments: premium, popular and economy. Judged by its pricing strategy, BAT used the premium and popular brands as profit drivers, while it used the economy brands to maintain its sales volume. By overshifting the excise tax increase on premium and popular brand cigarettes, the industry is likely to increase its profits, at least in the short run, through higher per-cigarette revenue.
From the tobacco industry's perspective, a drawback of overshifting the excise tax is that it may encourage competitors to enter the market, which may undercut the prices of the incumbent firm(s), as has been observed since 2010 in South Africa. ${ }^{11}$

BAT Mauritius's strategy of overshifting the excise tax has precedent in a number of countries, including the UK, Turkey, New Zealand, Taiwan and South Africa. ${ }^{12-16}$ If the dominant tobacco company has market power, it has price setting ability. If this strategy of over shifting the excise tax is applied to all cigarettes, the public health effect of an increase in the excise tax is amplified in the form of even higher retail prices.

The commercial genius of BAT Mauritius's pricing strategy was that overshifted the excise tax on the premium and popular brands, but it substantially undershifted the excise tax on economy brands. By undershifting the tax on economy cigarettes, it created an affordable range of cigarettes for smokers who can no longer afford the expensive premium and popular brands. More affordable cigarettes act as a disincentive to quit smoking and as an incentive for youngsters to start smoking. The presence of cheap cigarettes in the market also makes it difficult for potential competitors to enter the market and to undercut the prices of the incumbent brands.

While BAT Mauritius's pricing strategy is commercially smart, it is disastrous from a public health perspective. Because of the industry's pricing strategy, smoking prevalence in Mauritius is much higher than it should have been. This is not necessarily a failure of Mauritius's tobacco tax policy but a reflection of an industry strategy that has intentionally undermined it.

As in most market economies, the government of Mauritius cannot regulate the retail prices of cigarettes to prevent the tobacco industry from expanding the economy market segment. However, the government has control over the excise tax. Increasing the excise tax in Mauritius is administratively easy, illustrated by the fact that it has been increased six times since 2008. However, it would make no commercial sense for the tobacco industry to undershift excise tax increases indefinitely. The net-of-tax proportion of the retail price on economy cigarettes is already quite low (17.3\%). Should the government substantially increase the excise tax, the tobacco industry would have no option but to pass it through to consumers in the form of higher prices. The public health benefits, in the form of reduced prevalence of smokers, will follow.

\section{CONCLUSION}

This paper describes the tax and cigarette price situation in Mauritius since 2011. Mauritius's tax structure, regular tax increases and non-price tobacco control interventions have been in line with international best practice. The outcomes of these interventions, in terms of reduced cigarette consumption and lower smoking prevalence, have been disappointing.

The tobacco industry's pricing strategy has greatly undermined the country's tobacco control efforts. By undershifting the

Table 3 Summary statistics of the increases in tax and prices between 2011 and 2017

\begin{tabular}{|c|c|c|c|c|c|c|}
\hline & \multicolumn{3}{|c|}{ Percentage change } & \multicolumn{3}{|c|}{ Absolute change (Rs per pack, real values) } \\
\hline & Premium \% & Popular \% & Economy \% & Premium & Popular & Economy \\
\hline Real retail prices & 54 & 47 & 29 & 74 & 57 & 31 \\
\hline VAT $(15 \%)$ per pack & 54 & 47 & 29 & 10 & 7 & 4 \\
\hline Real excise tax & 47 & 47 & 47 & 31 & 31 & 31 \\
\hline Real net-of-tax prices & 62 & 47 & -15 & 33 & 18 & -4 \\
\hline
\end{tabular}

Source: Authors own calculation based on real prices and taxes data. 


\section{What this paper adds}

- Since 2008, Mauritius has applied a uniform specific tax on cigarettes, which has been increased at regular intervals in line with international best practice. However, the pricing strategies of the tobacco industry in Mauritius have undermined the public health benefits of the tax increases.

- Because it is a near monopoly, the tobacco industry in Mauritius has the pricing power to increase the retail price by more than the increase in the excise tax (ie, overshift the excise tax) and has applied this strategy for popular and premium cigarettes since 2011.

- For economy brands the tobacco industry decreased the net-of-tax price in response to an increase in the excise tax, which dampened the impact on the retail price. As a result, smokers who may have quit smoking cigarettes have an incentive not to do so, with detrimental public health consequences.

excise tax on economy brands, it has made these cigarettes more affordable than they would have been otherwise. The industry made up the reduced revenue in the economy brand market segment by substantially overshifting the excise tax increase on premium and popular brands.

The fact that the tobacco industry was able to largely dodge the effect of the tax increases through clever pricing strategies does not suggest that the tax system was wrong or misguided. At a certain point, the net-of-tax price becomes so low that the tobacco industry is not able to continue with its strategy of undershifting the tax increase. Mauritius is now at that point. Further increases in the excise tax are likely to result in increases in the retail price of economy brand cigarettes.

Contributors DM, CVW and MCS initiated the research. HS and BJ supervised the data collection in Mauritius. JBV compiled the database. MCS coordinated the data validation workshop with relevant stakeholders in Mauritius. JBV and CVW analysed the data. The results were synthesised and written by JBV, CVW and HR with inputs from the rest of the team.

Funding This study was funded by Cancer Research UK CRUK- C62640/A24723.

Competing interests None declared.

Patient consent for publication Not required.
Provenance and peer review Not commissioned; externally peer reviewed.

Open access This is an open access article distributed in accordance with the Creative Commons Attribution Non Commercial (CC BY-NC 4.0) license, which permits others to distribute, remix, adapt, build upon this work non-commercially, and license their derivative works on different terms, provided the original work is properly cited, appropriate credit is given, any changes made indicated, and the use is non-commercial. See: http://creativecommons.org/licenses/by-nc/4.0/.

\section{ORCID iD}

Julie Berthet Valdois http://orcid.org/0000-0001-9970-8102

\section{REFERENCES}

1 Azagba S, Burhoo P, Chaloupka FJ, et al. Effect of cigarette Tax increase in combination with mass media campaign on smoking behaviour in Mauritius: findings from the ITC Mauritius survey. Tob Control 2015;24(Supplement 3):iii71-5.

2 WHO. Who report on the global tobacco epidemic, 2008: the MPOWER package. Geneva: World Health Organization, 2008.

3 Ministry of Health and Quality of Life. National Action Plan on Tobacco Control: 2008 - 2012, 2008. Available: https://untobaccocontrol.org/impldb/wp-content/uploads/ reports/Annexfivemauritius.pdf

4 NCDS. The Mauritius Non Communicable Diseases Survey : The Trends in Diabetes and Cardiovascular Disease Risk in Mauritius, 2015Ministry of Health and Quality of Life (Republic of Mauritius). Available: http://health.govmu.org/English/Statistics/ Documents/Mauritius

5 NCDS. The Mauritius non communicable diseases survey: the trends in diabetes and cardiovascular disease risk in Mauritius, 2009Ministry of Health and Quality of Life (Republic of Mauritius). Available: health.govmu.org/English/Documents/ncd-2009.pdf

6 Mauritius- Budget Speech 2010-2017. Available: https://www.cabri-sbo.org/en/ countries/documents/p2?country\%5B\%5D=2668\&document_1\%5B\%5D=25639\& sort=year\&order $=$ desc

7 WHO tobacco control focal point in Mauritius. Core questionnaire of the reporting instrument of WHO FCTC, 2016.

8 WorldBank. Inflation consumer prices 2006-2017. Available: https://data.worldbank. org/indicator/FP.CPI.TOTL.ZG? end $=2017$ \&locations=MU\&start=2006

9 Burhoo P T, Fong G CK, Quah A, et al. Self-Reported price of cigarettes, consumption and compensatory behaviours in a cohort of Mauritian smokers before and after a Tax increase. Mauritius Institute of Health, 2013.

10 GlobalData. Mauritius cigarettes, 2018.

11 Vellios N, Ross H, Van Walbeek C. Illicit cigarette trade in South Africa: 2002 -. Tobacco Control 2017. forthcoming.

12 Gilmore AB, Tavakoly B, Taylor G, et al. Understanding tobacco industry pricing strategy and whether it undermines tobacco Tax policy: the example of the UK cigarette market. Addiction 2013;108:1317-26.

13 Keklik S, Gultekin-Karakas D. Anti-Tobacco control industry strategies in turkey. BMC Public Health 2018;18:282.

14 Marsh L, Cameron C, Quigg R, et al. The impact of an increase in excise tax on the retail price of tobacco in New Zealand. Tob Control 2016;25:458-63.

15 Van Walbeek C. Industry responses to the tobacco excise tax increases in South Africa. South African J Economics 2006;74:110-22.

16 Gao W, Sanna M, Branston JR, et al. Exploiting a low Tax system: non-tax-induced cigarette price increases in Taiwan 2011-2016. Tob Control 2019;28:e126-32. 